\title{
The formation of weed infestation of winter rye under organic farming system depending on the method of sowing and the use of seed dressing and mineral fertilizer
}

\author{
Kształtowanie się zachwaszczenia żyta uprawianego \\ w warunkach ekologicznego gospodarowania w zależności od sposobu \\ siewu oraz zastosowania zaprawy nasiennej i nawozu mineralnego
}

Ewa Tendziagolska, Piotr Kuc

\begin{abstract}
Summary
The field experiment was carried out in 2009-2011 at Swojec Experimental Station of the University of Environmental and Life Science in Wrocław. The aim of the studies was to compare two methods of sowing of winter rye (pure stand and variety mixture) that include an application of permitted fertilizer and seed dressing in organic farming and evaluation of weed infestation. Variety mixture of rye significantly decreased number of weeds both during tillering and flowering stages of rye as well as their dry weight in comparison with weed infestation in pure stand of rye. Winter rye grown in variety mixture was characterized by higher tillering and higher index of LAI (leaf area index) what resulted in beneficial shadowing and it was a consequence of lower weed infestation on the plots with three-variety mixture. Varying levels of agricultural practices did not significantly affect weed infestation, but it was noticed that the number of weeds and their dry weight were a little bit lower after the use of fertilizer Estakizeryt.
\end{abstract}

Key words: pure stand; cultivar mixture; mineral fertilizer; seed dressing

\section{Streszczenie}

Doświadczenie zostało założone w latach 2009-2011 w Rolniczym Zakładzie Doświadczalnym Swojec, należącym do Uniwersytetu Przyrodniczego we Wrocławiu. Badania miały na celu porównanie dwóch sposobów siewu żyta (siew czysty lub mieszanina odmianowa) z wykorzystaniem dozwolonego do stosowania w rolnictwie ekologicznym nawozu mineralnego oraz zaprawy nasiennej na stan i stopień zachwaszczenia łanu. Uprawa żyta w mieszaninie odmianowej przyczyniła się do istotnego zmniejszenia liczby chwastów zarówno w okresie krzewienia, jak i w terminie kwitnienia zboża oraz ich suchej masy w porównaniu do zachwaszczenia obserwowanego w życie uprawianym w siewie czystym. Żyto uprawiane w mieszaninie charakteryzowało się lepszym rozkrzewieniem oraz wyższym wskaźnikiem LAI (leaf area index - indeks pokrycia liściowego), co sprzyjało lepszemu zacienieniu łanu i w konsekwencji ograniczeniu zachwaszczenia na poletkach obsianych mieszanką trójodmianową. Zastosowane w doświadczeniu zróżnicowane poziomy agrotechniki nie wpływały istotnie na zmiany stopnia zachwaszczenia łanu żyta. Obserwowano tylko nieznaczne zmniejszenie liczby, jak i masy chwastów po aplikacji Estakizerytu.

Słowa kluczowe: zasiew czysty; mieszanina odmian; nawożenie mineralne; zaprawa nasienna

Uniwersytet Przyrodniczy we Wrocławiu

Katedra Kształtowania Agroekosystemów i Terenów Zieleni

PI. Grunwaldzki 24A, 50-363 Wrocław

ewa.tendziagolska@up.wroc.p 


\section{Wstęp / Introduction}

W ekologicznej produkcji roślinnej problem zachwaszczenia upraw jest jednym $\mathrm{z}$ priorytetowych, gdyż w warunkach zaniechania chemicznej regulacji inne dozwolone metody eliminujące chwasty $\mathrm{z}$ siedliska mogą być niewystarczające. Powodzenie zabiegów odchwaszczających w tym systemie rolnictwa zaczyna się od działań profilaktycznych, a także wyjątkowo starannie prowadzonej agrotechniki (Bond i Grundy 2001; Mason i wsp. 2007). Jednym ze sposobów tworzenia mniej dogodnych warunków do rozwoju chwastów jest stosowanie zasiewów mieszanych w obrębie gatunków, a także odmian roślin uprawnych. Strategiczną rolę odgrywają odmiany o zwiększonej konkurencyjności wobec chwastów (Hansen i wsp. 2008). Uprawy mieszane dodatkowo ograniczają nasilenie patogenów wywołujących choroby roślin (Mundt i wsp. 1995; Newton 1997; Tratwal 2008) oraz lepiej znoszą stres powodowany czynnikami abiotycznymi, co w konsekwencji przyczynia się do stabilniejszego plonowania zbóż. Dobierając odmiany do mieszaniny należy także zwrócić uwagę na ich cechy morfologiczne, które powinny być na tyle zróżnicowane, aby łan był zwarty, dzięki czemu zmniejszy się podatność na wyleganie i nastąpi lepsze współzawodnictwo z chwastami (Kaut i wsp. 2009).

Hipoteza badawcza zakłada, że siew mieszaniny odmianowej przyczyni się do ograniczenia zachwaszczenia w łanie żyta, a wykorzystanie dozwolonych do stosowania $\mathrm{w}$ rolnictwie ekologicznym zaprawy nasiennej i nawozu mineralnego poprawi warunki rozwoju żyta, dzięki czemu będzie ono bardziej konkurencyjne w stosunku do pojawiających się chwastów.

\section{Materiały i metody / Materials and methods}

Doświadczenie polowe założono w latach 2009-2011 w Rolniczym Zakładzie Doświadczalnym Swojec należącym do Uniwersytetu Przyrodniczego we Wrocławiu, w oparciu o metodę losowanych podbloków (split-plot), w trzech powtórzeniach. Powierzchnia poletek do zbioru wynosiła $32 \mathrm{~m}^{2}$. Gleba, na której zlokalizowano eksperyment należy do rzędu gleb brunatnoziemnych, typ: mada brunatna, podtyp: typowa (Roczniki Gleboznawcze 2011). Została ona wytworzona z piasku gliniastego lekkiego na piasku słabogliniastym, zaliczana jest do klasy IVb, kompleksu żytniego dobrego o $\mathrm{pH}=6,2$. Czynnikiem pierwszego rzędu był sposób siewu żyta: siew czysty odmiany Dańkowskie Złote oraz siew w mieszaninie trzech odmian (1:1:1) - Dańkowskie Złote, Walet, Warko. Żyto wysiano w ilości zapewniającej obsadę $450 \mathrm{szt} . / \mathrm{m}^{2}$. Przedplonem dla żyta był groch siewny pastewny uprawiany na nasiona. Odmiany wybrane do mieszaniny odznaczają się podobnymi wymaganiami siedliskowymi, zbliżoną wysokością - odpowiednio 154, 151 i $151 \mathrm{~cm}$ oraz porównywalną podatnością na wyleganie. Ponadto przeznaczone są do uprawy na terenie całego kraju (COBORU 2009). Jako czynnik drugiego rzędu przyjęto poziom zastosowanej agrotechnki: poziom 1 - nawóz Estakizeryt, poziom 2 - zaprawa nasienna Grevit + nawóz Estakizeryt. Na obiekcie kontrolnym nie stosowano ani zaprawy, ani nawozu. Nawóz Estakizeryt wyrównujący niedobory magnezu i siarki $\left(25 \% \mathrm{MgO}\right.$ i $\left.50 \% \quad \mathrm{SO}_{3}\right)$ stosowano w ilości $100 \mathrm{~kg} / \mathrm{ha}$ w okresie strzelania w źdźbło żyta. Zaprawa nasienna Grevit 200 SL to ekstrakt z grejpfruta - $200 \mathrm{~g} / 11$ środka.

Chwasty zwalczano wiosną po ruszeniu wegetacji żyta za pomocą brony chwastownika. Zachwaszczenie łanu zboża określono w dwóch terminach: w okresie krzewienia (BBCH 21-29) metodą ilościowo-jakościową na powierzchniach próbnych $0,2 \mathrm{~m}^{2}$ (4 powtórzenia na poletku) oraz w terminie kwitnienia żyta (BBCH 61-69) metodą ilościowo-wagową na powierzchniach próbnych $0,5 \mathrm{~m}^{2}$ (2 powtórzenia). Określono liczebność populacji gatunków chwastów oraz ich suchą masę.

Dodatkowo w fazie kwitnienia żyta przeprowadzono pomiar powierzchni asymilacyjnej liści za pomocą aparatu LAI 2000, a w trakcie dojrzałości pełnej żyta na każdym poletku zmierzono wysokość roślin na kolejnych 25 roślinach z rzędu środkowego.

Wyniki poddano analizie wariancji z wykorzystaniem testu t-Studenta przy poziomie istotności $\mathrm{p}=0,05$.

Pomimo zróżnicowanych warunków meteorologicznych w poszczególnych latach prowadzenia doświadczenia wpływ badanych czynników na zachwaszczenie łanu był zbliżony. Z tego względu wyniki badań przedstawiono jako średnie z lat 2009-2011.

\section{Wyniki i dyskusja / Results and discussion}

Jedynie sposób siewu żyta istotnie modyfikował liczbę chwastów (tab. 1). Wysiew mieszaniny odmianowej w stosunku do siewu czystego żyta przyczynił się do wyraźnego zmniejszenia liczebności chwastów. Zależność tę obserwowano w obu terminach badań. W okresie krzewienia zboża liczba niepożądanych roślin zmniejszyła się o $17,3 \%$, natomiast w trakcie kwitnienia żyta o $14,3 \%$ w porównaniu do oznaczonej w siewie czystym. Poziom agrotechniki nie przyczynił się do znaczących zmian stopnia zachwaszczenia łanu, obserwowano jedynie tendencję do nieistotnego zwiększenia liczby gatunków chwastów w warunkach zastosowania przedsiewnej zaprawy Grevit i nawożenia w trakcie wegetacji nawozem Estakizeryt. Najmniej zachwaszczone były poletka, na których zaaplikowano tylko nawóz mineralny.

Nie stwierdzono istotnych zależności dla współdziałania czynników doświadczalnych, zanotowano jedynie tendencje do niewielkiego ograniczenia liczby chwastów na poletkach obsianych mieszaniną oraz zasilonych nawozem magnezowo-siarkowym, natomiast więcej chwastów pojawiło się w łanie żyta czystego odmianowo, zaprawionego przed siewem zaprawą Grevit i nawożonego Estakizerytem.

Zasiewy mieszane, obok dobrze rozpoznanej zdolności ograniczenia presji ze strony patogenów, są postrzegane jako element agrotechniki przyczyniający się do zmniejszenia zachwaszczenia łanu. Jest to wynikiem lepszej konkurencyjności mieszaniny, przejawiającej się bardziej efektywnym wykorzystaniem zasobów siedliska (większy przyrost masy, a w konsekwencji większa zdolność konkurencyjna) w porównaniu do zasiewów czystych 
Tabela 1. Liczba chwastów w łanie żyta [szt. $\left./ \mathrm{m}^{2}\right]$

Table 1. Number of weeds in winter rye stand $\left[\mathrm{pcs} / \mathrm{m}^{2}\right]$

\begin{tabular}{|c|c|c|c|c|c|c|}
\hline \multirow{3}{*}{$\begin{array}{c}\text { Poziom agrotechniki } \\
\text { Level of agricultural practices }\end{array}$} & \multicolumn{6}{|c|}{ Sposób siewu-Method of sowing } \\
\hline & $\begin{array}{l}\text { siew czysty } \\
\text { pure sowing }\end{array}$ & $\begin{array}{l}\text { siew mieszany } \\
\text { mixture sowing }\end{array}$ & $\begin{array}{c}\text { średnio } \\
\text { mean }\end{array}$ & $\begin{array}{l}\text { siew czysty } \\
\text { pure sowing }\end{array}$ & $\begin{array}{l}\text { siew mieszany } \\
\text { mixture sowing }\end{array}$ & $\begin{array}{c}\text { średnio } \\
\text { mean }\end{array}$ \\
\hline & \multicolumn{3}{|c|}{ krzewienie - tillering } & \multicolumn{3}{|c|}{ kwitnienie - anthesis } \\
\hline Kontrola-Control & 76,2 & 61,7 & 69,0 & 62,7 & 52,5 & 57,6 \\
\hline Estakizeryt & 67,4 & 57,3 & 62,4 & 51,3 & 43,2 & 47,3 \\
\hline Grevit + Estakizeryt & 88,9 & 73,2 & 81,1 & 72,6 & 64,3 & 68,5 \\
\hline Średnio - Mean & 77,5 & 64,1 & - & 62,2 & 53,3 & - \\
\hline \multicolumn{4}{|c|}{$\begin{array}{l}\text { NIR }(0,05) \text { dla sposobu siewu - LSD }(0.05) \text { for method of sowing } \\
\text { NIR }(0,05) \text { dla poziomu agrotechniki }\end{array}$} & \multicolumn{3}{|c|}{7,5} \\
\hline
\end{tabular}

r.n. - różnica nieistotna - not significant difference

Tabela 2. Sucha masa chwastów $[\mathrm{g}]$

Table 2. Dry matter of weeds [g]

\begin{tabular}{l|c|c|c}
\hline \multirow{2}{*}{\begin{tabular}{c} 
Level of agricultural practices \\
\cline { 2 - 3 }
\end{tabular}} & $\begin{array}{c}\text { Siew czysty } \\
\text { pure sowing }\end{array}$ & $\begin{array}{c}\text { siew mieszany } \\
\text { mixture sowing }\end{array}$ & $\begin{array}{c}\text { Średnio } \\
\text { Mean }\end{array}$ \\
\hline Kontrola - Control & 95,4 & 71,3 & 83,4 \\
\hline Estakizeryt & 82,1 & 63,7 & 72,9 \\
\hline Grevit + Estakizeryt & 111,2 & 68,1 & 89,7 \\
\hline Średnio - Mean & 96,2 & 67,7 & - \\
\hline NIR (0,05) dla sposobu siewu - LSD (0.05) for method of sowing & 14,7 & \\
NIR (0,05) dla poziomu agrotechniki - LSD $(0.05)$ for level of agricultural practices \\
NIR $(0,0)$ dla interakcji - LSD $(0.05)$ for interaction \\
r.n. - różnica nieistotna - not significant difference
\end{tabular}

(Liebman i Dyck 1993). Zdolność tłumienia chwastów przez zasiewy mieszane jest także rozpatrywana pod kątem zjawiska allelopatii (Liebman i Dyck 1993; Pridham i wsp. 2007). Według Bertholdssona (2004) poszczególne odmiany tego samego gatunku mogą wykazywać różny potencjał allelopatyczny, stąd w zasiewach skomponowanych $\mathrm{z}$ kilku przedstawicieli gatunku aktywność wydzielanych do gleby allelopatyn może być większa, a przez to silniej hamująca rozwój chwastów niż w uprawach jednoodmianowych. Dlatego, jak podaje Parylak i wsp. (2006), wybór odmiany może mieć znaczny wpływ na aspekt ekonomiczny, gdyż właściwie dobrana odmiana będzie przyczyniać się do obniżenia kosztów związanych z regulacją zachwaszczenia, co ma duże znaczenie zwłaszcza w produkcji ekologicznej (Hansen i wsp. 2008).

Sucha masa chwastów, oznaczona w fazie kwitnienia żyta, była kształtowana przez zastosowane czynniki doświadczenia $\mathrm{w}$ podobnym stopniu, jak ich liczebność (tab. 2). Zasiew mieszany istotnie zmniejszył (o 29,6\%) biomasę chwastów w porównaniu do określonej w siewie czystym żyta. Nie wykazano matematycznie udowodnionych różnic dla poziomu agrotechniki oraz interakcji czynników. Zanotowano jedynie, że chwasty zebrane $\mathrm{z}$ trójodmianowej mieszanki żyta w warunkach stosowania nawozu, wytworzyły nieznacznie mniejszą biomasę niż chwasty pojawiające się w łanie żyta jednej odmiany, w warunkach najwyższego poziomu agrotechniki.
W badaniach Feledyn-Szewczyk i Duer (2006) nad ekologiczną pszenicą ozimą autorki wykazały większą suchą masę chwastów w mieszaninie odmianowej niż $\mathrm{w}$ siewie czystym. Było to wynikiem różnic w wysokości roślin wybranych do eksperymentu, odmiany pszenicy uprawiane jako zasiewy czyste były wyższe od zastosowanych w mieszaninach, a przez to bardziej konkurencyjne w stosunku do chwastów.

Zdolność do hamowania rozwoju chwastów przez poszczególne gatunki i ich odmiany jest wynikiem wielu cech rośliny ogólnie określanych jako konkurencyjność. Jej efektywność zależy m.in. od szybkości wschodów (Didon 2002), rozkrzewienia (Lemerle i wsp. 1996), wysokich wartości indeksu powierzchni asymilacyjnej liści (LAI) (Huel i Hucl 1996; Seavers i Wright 1999) oraz wysokości łanu (Christensen 1995; Owczarczuk i wsp. 2005; Tendziagolska i Kuc 2012).

W badaniach własnych wykazano, że żyto zebrane z zasiewów mieszanych było nieistotnie niższe niż żyto czyste odmianowo (tab. 3), jednak istotnie bardziej (o $10,5 \%$ ) rozkrzewione (tab. 4). Zarówno poziom agrotechniki, jak i interakcja czynników doświadczalnych nie spowodowały znaczących zmian odnośnie obu badanych cech. Konsekwencją wytworzenia większej liczby źdźbeł przez żyto uprawiane w mieszaninie był istotnie wyższy (o 11,7\%) wskaźnik ulistnienia od oznaczonego w łanie żyta jednej odmiany (tab. 4). Zasilanie roślin nawozem 
Tabela 3. Wysokość roślin [cm]

Table 3. Length of plants [cm]

\begin{tabular}{l|c|c|c}
\hline \multirow{2}{*}{$\begin{array}{c}\text { Poziom agrotechniki } \\
\text { Level of agricultural practices }\end{array}$} & $\begin{array}{c}\text { Sposób siewu - Method of sowing } \\
\text { pure sowing }\end{array}$ & $\begin{array}{c}\text { siew mieszany } \\
\text { mixture sowing }\end{array}$ & $\begin{array}{c}\text { Średnio } \\
\text { Mean }\end{array}$ \\
\cline { 2 - 4 } & 140,5 & 137,8 & 139,2 \\
\hline Kontrola - Control & 142,6 & 136,1 & 139,4 \\
\hline Estakizeryt & 144,1 & 134,8 & 139,5 \\
\hline Grevit + Estakizeryt & 142,4 & 136,2 & - \\
\hline
\end{tabular}

NIR $(0,05)$ dla sposobu siewu - LSD $(0.05)$ for method of sowing

NIR $(0,05)$ dla poziomu agrotechniki - LSD $(0.05)$ for level of agricultural practices

NIR $(0,05)$ dla interakcji - LSD $(0.05)$ for interaction

r.n. - różnica nieistotna - not significant difference

Tabela 4. Rozkrzewienie efektywne oraz indeks pokrycia liściowego żyta (LAI)

Table 4. Effective tillering and leaf area index of winter rye (LAI)

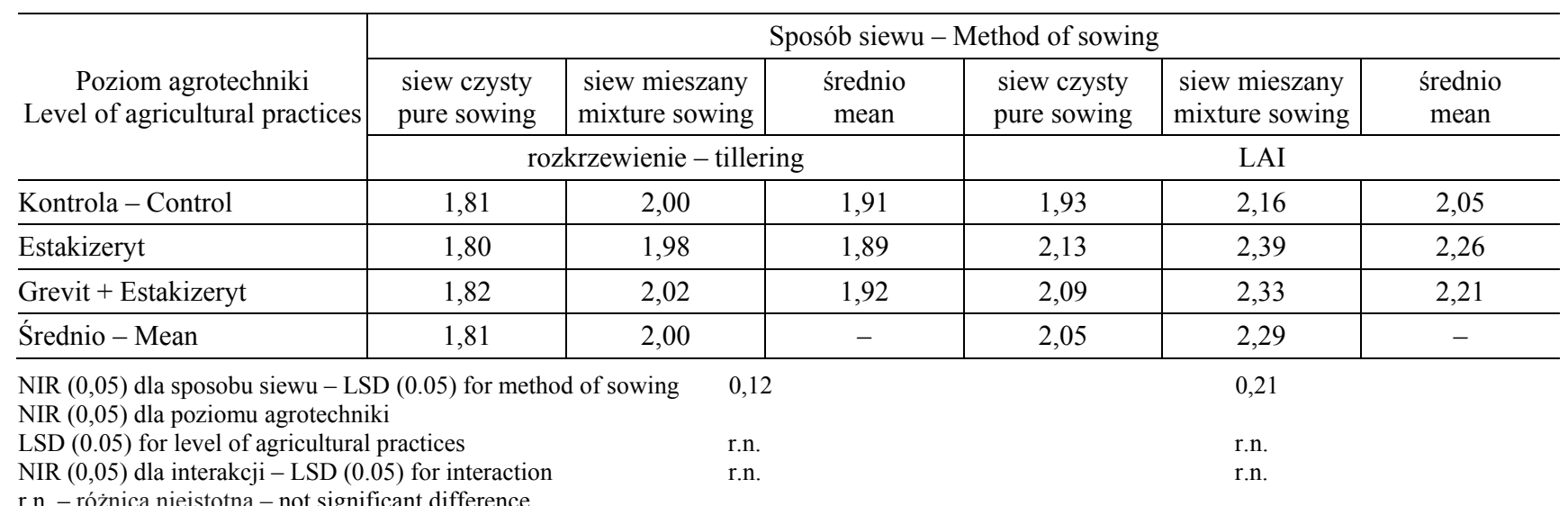

- roznica nieistotna - not significant differ

LAI - wskaźnik pokrycia liściowego - leaf area index

Estakizeryt sprzyjało niewielkiej poprawie wskaźnika ulistnienia roślin zarówno w warunkach siewu jedno-, jak i kilkuodmianowego.

Większa powierzchnia asymilacyjna liści skutkuje lepszym zacienieniem w łanie, dzięki czemu chwasty mają mniej dogodne warunki do rozwoju. Rezultaty badań własnych potwierdzają wyniki Drews i wsp. (2002), którzy donoszą o możliwości zwiększenia konkurencyjności odmian pszenicy wobec chwastów poprzez sterowanie zacienieniem w łanie.

\section{Wnioski / Conclusions}

1. Uprawa żyta $\mathrm{w}$ mieszaninie odmianowej przyczyniła się do istotnego zmniejszenia liczby chwastów zarówno w okresie krzewienia, jak i w terminie kwitnienia zboża w porównaniu do zachwaszczenia obserwowanego w życie uprawianym w siewie czystym.

2. Sucha masa chwastów określona w terminie kwitnienia żyta zależała istotnie od sposobu siewu. Zastosowanie mieszaniny odmianowej sprzyjało wyraźnemu zmniejszeniu suchej masy chwastów w porównaniu do biomasy określonej w siewie czystym żyta.

3. Żyto uprawiane w mieszaninie było nieznacznie niższe od uprawianego w siewie czystym, za to bardziej rozkrzewione i o wyższym wskaźniku ulistnienia, co sprzyjało lepszemu zacienieniu łanu i w konsekwencji ograniczeniu zachwaszczenia na poletkach obsianych mieszanką trójodmianową.

4. Zastosowane $\mathrm{w}$ doświadczeniu zróżnicowane poziomy agrotechniki nie wpływały istotnie na zmiany stopnia zachwaszczenia łanu żyta. Obserwowano tylko nieznaczne zmniejszenie liczby, jak i masy chwastów po aplikacji Estakizerytu.

\section{Literatura / References}

Bertholdsson N.O. 2004. Variation in allelopathic activity over one hundred years of barley selection and breeding. Weed Res. 44 (2): $78-86$.

Bond W., Grundy A.C. 2001. Non-chemical weed management in organic farming systems. Weed Res. 41 (5): $383-405$.

Christensen S. 1995. Weed suppression ability of spring barley varieties. Weed Res. 35: 241-247.

Didon U.M. 2002. Variation between barley cultivars in early response to weed competition. J. Agron. Crop Sci. 188 (3): $176-184$. 
Drews S., Neuhoff D., Juroszek P., Kpie U. 2002. Einfluss von Sortenwahl, Reihenweite und Drillrichtung auf die Konkurrenzkraft von Winterweizen im organischen Landbau. Z. Pflanzenrankh. Pflanzensch., Sonderheft 18: 527-532.

Feledyn-Szewczyk B., Duer I. 2006. Ocena konkurencyjności odmian pszenicy ozimej uprawianej w ekologicznym systemie produkcji w stosunku do chwastów. J. Res. Appl. Agric. Engin. 51 (2): 30-35.

Hansen P.K., Kristensen K., Willas J. 2008. A weed suppressive index for spring barley (Hordeum vulgare) varieties. Weed Res. 48 (3): $225-236$

Huel D.G., Hucl P. 1996. Genotypic variation for competitive ability in spring wheat. Plant Breeding 115: 325-329.

Kaut A.H.E.E., Mason H.E., Navabi A., O'Donovan J.T., Spaner D. 2009. Performance and stability of performance of spring wheat variety mixtures in organic and conventional management systems in western Canada. J. Agric. Sci. 147 (2): $141-153$.

Lemerle D., Verbeek B., Cousens R.D., Coombes N.E. 1996. The potential for selecting wheat varieties strongly competitive against weeds. Weed Res. 36 (6): 505-513.

Liebman M.L. 1995. Polyculture cropping systems. p. 205-218. In: "Acroecology: The Science of Sustainable Agriculture". Second Edition (M.A. Altieri, ed.). Westview Press: Boulder, Colorado, 576 pp.

Liebman M., Dyck E. 1993. Crop rotation and intercropping strategies for weed management. Ecol. Appl. 3 (1): 92-122.

Mason H., Navabi A., Frick B., O'Dovan J., Spaner D. 2007. Cultivar and seeding rate effects on the competitive ability of spring cereals grown under organic production in Northern Canada. Agron. J. 99 (5): 1199-1207.

Mundt C.C., Brophy L.S., Schmitt M.S. 1995. Disease severity and yield of pure-line wheat cultivars and mixtures in the presence of eyespot, yellow rust, and their combination. Plant Pathol. 44 (1): 173-182.

Newton A.C. 1997. Cultivar mixtures in intensive agriculture. p. 65-79. In: "The Gene-for-Gene Relationship in Plant-Parasite Interactions" (I.R. Crute, E.B. Holub, J.J. Burdon, eds). CAB International, London, UK, 266 pp.

Owczarczuk A., Snarska K., Jędruszczak M. 2005. Odmiana a zachwaszczenie łanu żyta ozimego. [Cultivar and weed infestation of winter rye canopy]. Prog. Plant Prot./Post. Ochr. Roślin 45 (2): 970-973.

Parylak D., Zawieja J., Jędruszczak M., Stupnicka-Rodzynkiewicz E., Dąbkowska T., Snarska K. 2006. Wykorzystanie zasiewów mieszanych, właściwości odmian lub zjawiska allelopatii w ograniczaniu zachwaszczenia. [Use of the mixed crops, cultivar properties or allelopathy in weed control]. Prog. Plant Prot./Post. Ochr. Roślin 46 (1): 33-44.

Pridham J.C., Entz M.H., Martin R.C., Hucl P.J. 2007. Weed, disease and grain yield effects of cultivar mixtures in organically managed spring wheat. Can. J. Plant Sci. 87 (4): 855-859.

Seavers G.P., Wright K.J. 1999. Crop canopy development and structure influence weed suppression. Weed Res. 39 (4): $319-328$.

Roczniki Gleboznawcze. 2011. Soil Science Annual. Systematyka gleb Polski 62 (3): 5-142.

Tratwal A. 2008. Mieszanki odmian jako alternatywa uprawy zbóż w rolnictwie zrównoważonym i ekologicznym. Ann. UMCS, Sec. E, 63 (2): $38-45$.

Tendziagolska E., Kuc P. 2012. Zachwaszczenie owsa w siewie jednoodmianowym i mieszance trzech odmian w warunkach ekologicznego gospodarowania. [Weed infestation of oats in one variety and mixture of three varieties stands under organic farming]. Prog. Plant Prot./Post. Ochr. Roślin 52 (2): 318-322. 